\title{
Effects of a pain programme on nurses' psychosocial, physical and relaxation interventions
}

\author{
Anneke L. Francke ${ }^{a, *}$, J. Bart Luiken ${ }^{a}$, Bert Garssen ${ }^{\text {a }}$, Huda Huijer Abu-Saad ${ }^{\text {, }}$, \\ Mieke Grypdonck ${ }^{\mathrm{c}, \mathrm{d}}$ \\ ${ }^{a}$ Helen Dowling Institute, Mathenesserlaan 183, 3014 HA Rotterdam, Netherlands \\ ${ }^{\mathrm{b}}$ Department of Nursing Science, University of Limburg, Maastricht, Netherlands \\ 'Department of Nursing Science, University of Utrecht, Utrecht, Netherlands \\ ${ }^{\mathrm{d}}$ Department of Nursing Science, University of Gent, Gent, Belgium
}

Received 15 May 1995; revised 20 November 1995; accepted 4 December 1995

\begin{abstract}
The effectiveness of a continuing education programme on pain assessment and management was investigated in 106 surgical cancer nurses. It was found that the programme led to a more positive attitude towards physical and relaxation interventions (such as the use of relaxation, distraction and massage techniques). In addition, an increase in the duration and quality of psychosocial interventions (provision of information, emotional support, and promotion of autonomy) was established. Furthermore, the programme resulted in an increase in the quality of physical and relaxation interventions. However, the programme did not lead to more positive attitudes towards psychosocial interventions, or to increases in the numbers of psychosocial, physical and relaxation interventions.
\end{abstract}

Keywords: Pain; Nursing; Continuing education; Training

\section{Introduction}

Several meta-analytic studies have pointed to a positive effect of systematic provision of information and emotional support on post-surgical pain [1-4]. In addition, there is empirical evidence that promotion of autonomy, for instance by actively involving patients in decisions about their analgesia, may result in a decrease of post-

\footnotetext{
* Corresponding author. Tel.: + 3110 4363977; fax: + 3110
} 4.367165 . surgical pain $[5,6]$. On the basis of descriptive studies [7-9] it can be assumed that nurses do apply such psychosocial interventions frequently, but that the duration and quality of the interventions are sometimes not optimal. For instance, discussions with patients are frequently brief and superficial $[7,9]$.

Research has also been done in the area of physical and relaxation interventions. Studies indicate that when nurses promote patients' relaxation, e.g. through breathing or muscle relaxation exercises, this has a favourable impact 
on post-operative pain [10-12]. Distraction $[13,14]$, physical and environmental comfort measures $[15,16]$, massage $[17,18]$ and the use of cold and heat $[17,19]$ also relieve pain. Nevertheless, most physical and relaxation interventions are used on a modest scale in nursing $[8,20-23]$.

Continuing education is often recommended as a way for reducing lacunas in pain assessment and management practices $[24,25]$ and several publications have appeared in recent years on pain programmes for nurses [26]. However, only two published programmes tracked down $[25,27]$ paid attention on nurses' psychosocial and physical and relaxation interventions (besides other programme topics). Further research in this field is thus advisable, which prompted an intervention study on the effects of a pain assessment and management programme directed to Dutch surgical cancer nurses. In this article the following research questions will be dealt with:

Did the programme lead to:

- a more positive attitude towards psychosocial and physical and relaxation interventions?

- an increase in

- the number of psychosocial interventions?

- the duration of psychosocial interventions?

- the quality of psychosocial interventions?

- an increase in

- the number of physical and relaxation interventions?

- the quality of physical and relaxation interventions?

\section{Methods}

\subsection{Sample}

In this intervention study, five Dutch general hospitals were involved. The hospitals were chosen on the basis of geographical proximity. Entry to the hospitals was gained by contacting medical-ethical committees, nursing directors and physicians. In each hospital, two surgical wards were involved that contained both cancer and noncancer patients. In principle, all certified nurses in the 10 wards involved were expected to cooperate in the study. Six of a total sample of 134 nurses did not, however, lend their assistance (reasons: noncompliance, $n=2$; practical impossibility, $n=2$; illness/pregnancy $n=2$ ). All 128 nurses participating in the study met the following inclusion criteria: completed basic nursing education and involved in direct patient care activities. Of the 128 research subjects, 22 dropped out of the study (reasons: noncompliance, $n=3$; illness/pregnancy, $n=4$; discharge, $n=8$; function change, $n=7$ ). One of these 22 nurses also discontinued participation in the programme. The effects of the programme were determined on the basis of data from the 106 nurses who remained in the study until the last measurement point.

\subsection{The programme}

The continuing education programme on pain assessment and management consisted of eight weekly 3-h sessions. A follow-up meeting was held 4 months after the end of the weekly sessions. Major programme components were the transfer of knowledge and skills, and the mutual exchange of learning experiences with respect to:

(a) pain and the assessment of pain (e.g. the uniqueness and subjectivity of pain, and characteristics of pain which should be assessed)

(b) pharmacological pain management (e.g. types, mode of action and effects of opioids and nonopioids);

(c) psychosocial interventions (giving information and emotional support, and promotion of autonomy),

(d) physical and relaxation interventions (use of massage, relaxation, distraction, cold/ heat, and physical and environmental comfort measures).

Approximately 3 contact hours were devoted to program item a, 4.5 to item $b, 7.5$ to item c, and 6 to item $\mathrm{d}$. The remaining contact hours had a more general character (e.g. group evaluations). Various didactic strategies were used: introductions by the instructors, discussions by 
the group as a whole and in small groups, audiovisual presentation, practical exercises and provision of relevant literature [28]. The programme took place in a room in the participating hospital and was presented by two instructors: one with a professional background in nursing, psychotherapy and nursing education and the other with a background in adult education.

\subsection{Design}

Effects of the programme were measured in a pretest-posttest control group design. For each of the five hospitals, random allocation was performed to decide which of the two wards would be in the experimental condition (programme) and which in the control condition (no programme). Nurses in both conditions filled in a set of questionnaires at three measurement points: just before the start of the programme $\left(\mathrm{T}_{1}\right) ; 1$ month after the end of the programme $\left(\mathrm{T}_{2}\right)$; and 6 months after the end of the programme $\left(T_{3}\right)$.

\subsection{Instruments}

The following instruments were used for measuring outcome variables (questionnaires used for measuring background characteristics are not included. See relevant literature references in Table 1).

The Questionnaire on Attitudes Towards Psychosocial and Physical and Relaxation Interventions is a 15-item self-developed questionnaire used to assess nurses' attitudes towards psychosocial, physical and relaxation interventions. Attitude in this context refers to the respondent's 'evaluative beliefs' [29] with respect to the usefulness of interventions. All of the items include a scale of $0-10$ and a 'no opinion' option. For example, this item:

Is teaching patients how to relax muscles a useful pain control method in your work?

$$
\begin{array}{ll}
\begin{array}{l}
\text { Absolutely } 012345678910 \\
\text { unuseful =0 }
\end{array} & \begin{array}{l}
\text { Extremely } \\
\text { useful }=10
\end{array} \\
{[\text { ] = no opinion }} &
\end{array}
$$

The questionnaire was developed because there were no instruments in the Dutch language for measuring attitudes towards psychosocial, physical and relaxation interventions that could stand up to methodological examination. Eight pain experts evaluated the questionnaire's content validity. The questionnaire was tested (with encouraging results) on 15 nurses who did not participate in other parts of the study. Subsequently, the structure and internal consistency was determined using the data of the 106 research subjects of the intervention study. A principal component analysis for ordinal data showed that the new questionnaire is two-dimensional. The first dimension (Cronbach's Alpha $=0.69$ ) concerns attitudes towards psychosocial interventions, while the second dimension (Cronbach's Alpha $=0.85$ ) measures the attitude towards physical and relaxation interventions. For calculating the scores for each dimension, item scores were added up and, subsequently, divided by the total number of items of that particular dimension.

The Adjusted Therapeutic Behaviour Scale is a 35-item questionnaire used to determine effects on number, duration and quality of psychosocial interventions. 'Quality' in this context refers to the way in which interventions are executed. The Adjusted Therapeutic Behaviour Scale is an adaptation of Pool's Therapeutic Behaviour Scale [5]. Every item of the Adjusted Therapeutic Behaviour Scale includes the same 'number, duration and quality answer categories' (categories A, B and C, respectively). For example:

To inform patients about what they can do to avoid (worse) pain.

A The average number of times I practiced this intervention in the past month is:

$\square 1$ or more times a day

$\square$ 1-4 timcs a week

$\square$ 1-3 times during the entire past month

$\square$ None at all

B Each time I practice this intervention I spend: 
Table 1

Differences in background characteristics of 'remaining' research subjects and 'drop outs'

\begin{tabular}{|c|c|c|c|c|c|c|c|}
\hline \multirow{2}{*}{$\begin{array}{l}\text { Background } \\
\text { characteristics }\end{array}$} & & \multicolumn{3}{|c|}{ Remaining research subjects $(n=106)$} & \multicolumn{3}{|c|}{ Drop outs $(n=22)$} \\
\hline & & $\begin{array}{l}\text { Experimental } \\
(n=48)\end{array}$ & $\begin{array}{l}\text { Control } \\
(n=58)\end{array}$ & $\begin{array}{l}\text { Test } \\
(n=10)\end{array}$ & $\begin{array}{l}\text { Experimental } \\
(n=12)\end{array}$ & Control & Test \\
\hline \multirow[t]{2}{*}{ Sex } & Female & $97.9 \%$ & $93.1 \%$ & $\begin{array}{l}\chi^{2}=1.35 \\
d f=1\end{array}$ & $80.0 \%$ & $83.3 \%$ & $\begin{array}{l}\chi^{2}=0.041 \\
d f=1\end{array}$ \\
\hline & Male & $2.1 \%$ & $6.9 \%$ & $P=0.25$ & $20.0 \%$ & $25.0 \%$ & $P=0.84$ \\
\hline \multirow[t]{2}{*}{ Function } & $\begin{array}{l}\text { Head nurse/ } \\
\text { team leader }\end{array}$ & $16.7 \%$ & $17.2 \%$ & $\begin{array}{l}\chi^{2}=0.006 \\
d f=1\end{array}$ & $30.0 \%$ & $25.0 \%$ & $\begin{array}{l}\chi^{2}=0.069 \\
d f=1\end{array}$ \\
\hline & Nurse & $83.3 \%$ & $82.8 \%$ & $P=0.94$ & $70.0 \%$ & $75.0 \%$ & $P=0.79$ \\
\hline \multirow[t]{2}{*}{ Educational level } & $\begin{array}{l}\mathrm{HBO}^{\mathrm{a}} \\
\text { or greater }\end{array}$ & $31.25 \%$ & $41.4 \%$ & $\begin{array}{l}\chi^{2}=1.96 \\
d f=1\end{array}$ & $55.6 \%$ & $41.7 \%$ & $\begin{array}{l}\chi^{2}=0.398 \\
d f=1\end{array}$ \\
\hline & $\mathrm{MBO}^{\mathrm{a}}$ & $68.75 \%$ & $56.9 \%$ & $P=0.38$ & $44.4 \%$ & $58.3 \%$ & $P=0.53$ \\
\hline \multirow{2}{*}{$\begin{array}{l}\text { Participation in } \\
\text { pain programme } \\
\text { within past } 2 \text { years }\end{array}$} & Yes & $14.58 \%$ & $15.5 \%$ & $\begin{array}{l}\chi^{2}=0.008 \\
d f=1\end{array}$ & $22.2 \%$ & $0 \%$ & $\begin{array}{l}\chi^{2}=2.947 \\
d f=1\end{array}$ \\
\hline & No & $85.42 \%$ & $84.5 \%$ & $P-0.93$ & $77.8 \%$ & $100 \%$ & $P-0.086$ \\
\hline \multicolumn{2}{|c|}{ Age in years (mean (S.D.)) } & $31.4(9.7)$ & $29.9(7.1)$ & $\begin{array}{l}t=-0.84 \\
d f=82,4 \\
P=0.401\end{array}$ & $29.8(7.4)$ & $26.3(4.6)$ & $\begin{array}{l}t=-1.24 \\
d f=12,95 \\
P=0.24\end{array}$ \\
\hline \multicolumn{2}{|c|}{ Years certified (mean (S.D.)) } & $7.1(8.1)$ & $7.2(7.9)$ & $\begin{array}{l}t=0.02 \\
d f=103 \\
P=0.986\end{array}$ & $6.1(6.2)$ & $3.2(3.9)$ & $\begin{array}{l}t=-1.25 \\
d f=12,68 \\
P=0.24\end{array}$ \\
\hline \multicolumn{2}{|c|}{$\begin{array}{l}\text { General work satisfaction }{ }^{\mathrm{b}} \\
{\text { (rangc: } 7-35)^{\mathrm{c}}}^{(\text {mean }(\text { S.D.)) }}\end{array}$} & $28.7(3.2)$ & $29.1(3.9)$ & $\begin{array}{l}t=0.47 \\
d f=82 \\
P=0.64\end{array}$ & $\begin{array}{l}26.7(3.0) \\
P=0.76\end{array}$ & $26.1(4.3)$ & $\begin{array}{l}t=-0.32 \\
d f=14\end{array}$ \\
\hline \multicolumn{2}{|c|}{$\begin{array}{l}\text { Experienced work load } \\
\text { (range: } 4-20)^{\mathrm{c}} \\
\text { (mean (S.D.)) }\end{array}$} & $10.9(2.6)$ & $10.8(2.6)$ & $\begin{array}{l}t--0.07 \\
d f=80 \\
P=0.94\end{array}$ & $\begin{array}{l}12.2(4.2) \\
P=0.37\end{array}$ & $10.3(3.4)$ & $\begin{array}{l}t--0.94 \\
d f=13\end{array}$ \\
\hline \multicolumn{2}{|c|}{$\begin{array}{l}\text { Experienced job responsibility } \\
{\text { (range: } 3-15)^{\mathrm{b}}}^{\mathrm{c}} \\
(\text { mean (S.D.)) }\end{array}$} & $11.7(1.7)$ & $11.8(2.0)$ & $\begin{array}{l}t=0.23 \\
d f=8,62 \\
P=0.64\end{array}$ & $\begin{array}{l}10.4(2.8) \\
P=0.82\end{array}$ & $11.0(1.5)$ & $\begin{array}{l}t=0.49 \\
d f=81\end{array}$ \\
\hline \multicolumn{2}{|c|}{$\begin{array}{l}\text { Sensitivity to social desirability } \\
{\text { (range: } 0-8)^{\mathrm{c}}} \\
\text { (mean (S.D.)) }\end{array}$} & $5.1(1.8)$ & $5.0(2.0)$ & $\begin{array}{l}t=0.16 \\
d f=79 \\
P=0.87\end{array}$ & - & - & - \\
\hline
\end{tabular}

a $\mathrm{HBO}=$ Dutch higher professional education level, $\mathrm{MBO}=$ Dutch secondary professional education level.

'Measured with Boumans' work satisfaction scale [32].

"The most favourable scores are in italic type.

d Determined only for the group of nurses that participated until $\mathrm{T}_{3}$, and was measured with eight randomly chosen items from the Dutch-languaged Marlowe Crowne Social Desirability Scale [33].

Less time than the first time I completed this questionnaire

$\square$ The same amount of time as the first time I completed this questionnaire

$\square$ More time than the first time I completed this questionnaire
C Is the way you practice this intervention different from the way you did when you completed the questionnaire the first time?
$\square$ Yes
$\square$ No
$\square$ Not applicable 
If yes, briefly describe the change:

An earlier version of the questionnaire was tested, and established as practicable, in a pilot study with 10 nurses [30]. Subsequently, the structure and internal consistency were determined using the scores on the number-answer category' of the 106 research subjects in the intervention study. In order to be able to present changes in number, duration and quality of interventions every time for the same group of items, we determined the questionnaire's structure on the basis of only one answer category. Particularly the 'number-answer category' was chosen because its formulation made it the most suitable for determining the structure. A principal component analysis for ordinal data indicated that the Adjusted Therapeutic Behaviour Scale has two dimensions. The first dimension (Cronbach's Alpha $=0.91$ ) concerns general psychosocial interventions. With the term 'general', we mean not specifically focused on the pain problem of the patient. Dimension 2 (Cronbach's Alpha $=0.78)$ is related to pain-focused psychosocial interventions. The scores for each dimension were calculated as follows. For the 'number answer category': the answers on each item were converted into precise number of interventions. (The precise numbers were $80 \times, 12 \times, 2 \times$ or 0 $\times$ per month, respectively. For more information about reasons for and procedures of conversion, we refer to the questionnaire's handbook; available on request.) Then the precise numbers were added up and divided by the number of items in that dimension. For the 'duration answer category': the number of items on which less time was spent on an intervention was subtracted from the number of items on which more time was spent on an intervention. For the 'quality answer category': respondents' open answers were first studied to evaluate whether there was an increase, a decrease or no change in quality. This was done for each item by both the first author and an independent evaluator. When their evaluations did not correspond (which was the case in less than $5 \%$ of the answers), the respondent's answer on that item was treated in the analysis as 'missing.' Subsequently, for each respondent the number of items indicating a decrease in quality was subtracted from the number of items indicating an increase.

The Physical and Relaxation Interventions Questionnaire is a 12-item questionnaire used to determine changes in number and quality of physical and relaxation interventions. All of the items are succeeded by the same 'number and quality answcr catcgorics' (catcgory A and B, respectively). For example:

To teach a patient how to relax by breathing in a particular way

A The average number of times I practiced this intervention in the past month is:

$\square 1$ or more times a day

$\square$ 1-4 times a week

$\square$ 1-3 times during the entire past month

None at all

$B$ Is the way you practice this intervention different from the way you did when you completed the questionnaire the first time?

$$
\begin{aligned}
& \square \text { Yes } \\
& \square \text { No } \\
& \square \text { Not applicable }
\end{aligned}
$$

If yes, briefly describe the change:

The content validity and practicability of the Physical and Relaxation Interventions was established in the same way as performed by the Questionnaire on Attitudes towards Psychosocial and Physical and Relaxation Interventions (above). A principal component analysis for ordinal data revealed that the questionnaire has a unidimensional structure (Cronbach's Alpha $=0.70$ ). The calculations and evaluations of the scores on the answer categories were performed in the same way as described with respect to the 'number and duration answer categories' of the Adjusted Therapeutic Behaviour Scale.

\subsection{Data collection}

Two to three weeks before each of the three measurement points, the nurses from both conditions were requested to complete and return a 
set of questionnaires within 3 weeks. Whenever nurses did not return the questionnaires before the set date, they were approached by the researcher and again asked to submit them. This was not complied with in three cases.

\subsection{Statistical analyses}

For testing differences in background characteristics, the Student $t$-test was used for continual data and the $\chi^{2}$ test for categorical data (with a significance level of 0.05 , both sided). Effects of the programme were determined by MANCOVA for repeated measures, with statistical adjustment for the variable 'Hospital'. Multivariate testing of the interaction between measurements and conditions took place for each outcome variable separately. Because it was expected that the programme would only result in positive effects, one-sided testing was applied (with a significance level of 0.05). Data of some outcome variables (Tables 3,4 ) initially did not meet MANCOVA's assumption of normality [31] and, thereforc, on these data a root transformation was applied.

\section{Results}

\subsection{Background characteristics}

There were no significant differences between experimental and control nurses with respect to relevant background characteristics (Table 1). This applied to both the 'remaining' group at $\mathrm{T}_{3}$ $(n-106)$ and the group of 'drop outs' $(n=22)$.

\subsection{Attitudes towards psychosocial and physical and relaxation interventions}

As shown in Table 2, attitudes of experimental nurses towards psychosocial interventions remained virtually unchanged over the three measurement points. This was the same for control nurses. Consequently, no significant difference in trend between the two groups of nurses was established. However, in the attitudes of experimental nurses towards physical and relaxation interventions a positive change over the three measurement points occurred (Table 2). In the control condition, there was not such a positive change, even a small negative change at $\mathrm{T}_{2}$. Accordingly, there is a significant difference in trend between the experimental and control conditions, on the basis of which it can be concluded that the programme had a positive effect on nurses' attitudes with regard to physical and relaxation interventions.

\subsection{Psychosocial interventions}

\subsubsection{Number}

During the research period, the number of general psychosocial interventions varied, both in the experimental and control conditions (Table 3 ). The programme did not seem to have had any effect in this respect, which can be derived from the fact that there is no significant difference in trend between experimental and control nurses. The number of pain-focused psychosocial interventions also varied during the research period in both groups, and also in this case testing showed

Table 2

Mean scores on attitudes towards psychosocial and physical and relaxation interventions

\begin{tabular}{|c|c|c|c|c|c|}
\hline Attitudes & Condition & $\mathrm{T}_{1}$ & $\mathrm{~T}_{2}$ & $\mathrm{~T}_{3}$ & Measurements $\times$ condition \\
\hline $\begin{array}{l}\text { Towards psychosocial } \\
\text { interventions }\end{array}$ & Experimental & $7.7(1.7)$ & $7.6(1.4)$ & $7.6(1.3)$ & $\begin{array}{l}F=1.06 \\
d f=2,103\end{array}$ \\
\hline (range: $0-10)^{a}$ & Control & $7.3(1.4)$ & $7.1(1.8)$ & $7.4(1.3)$ & $P=0.18$ \\
\hline $\begin{array}{l}\text { Towards physical and } \\
\text { relaxation interventions }\end{array}$ & Experimental & $5.6(1.5)$ & $6.3(1.5)$ & $6.2(1.5)$ & $\begin{array}{l}F=7.34 \\
d f=2,101\end{array}$ \\
\hline (range: $0-10)^{a}$ & Control & $5.8(1.3)$ & $5.6(1.5)$ & $6.0(1.4)$ & $P<0.001$ \\
\hline
\end{tabular}

"The most favourable scores are in italic type. 
no significant difference in trend between the two groups of nurses (Table 3).

\subsubsection{Duration}

One month after the programme and, to a lesser extent, 6 months after the programme, experimental nurses indicated that they spend more time on general psychosocial interventions (Table 3 ). Control nurses virtually showed no increase, and there was a significant difference in trend between the two groups of nurses. The conclusion is that the programme resulted in an increase in the duration of general psychosocial interventions.

Experimental nurses also show an increase in the duration of pain-focused psychosocial interventions (Table 3). This increase is the greatest soon after the programme $\left(T_{1}\right)$. Control nurses demonstrate no obvious change, neither in the short nor the long term. There is a significant difference in trend between both groups of nurses, and the conclusion is that the programme resulted in an increase in the duration of painfocused psychosocial interventions.

\subsubsection{Quality}

Table 3 shows an increase in the quality of experimental nurses' general psychosocial interventions. At none of the measurement points an obvious increase in the quality of control nurses' general psychosocial interventions can be seen. Testing discloses that there is a significant difference in trend between the two groups of nurses. It can, therefore, be stated that the programme led to an increase in the quality of general psychosocial interventions.

Experimental nurses demonstrate an increase in the quality of their pain-focused psychosocial interventions as well (Table 3); this increase is also most obvious soon after the programme $\left(\mathrm{T}_{2}\right)$. Control nurses do not show any apparent increase, neither in the short nor long term. The difference in trend between experimental and control nurses is significant. Consequently, it can be concluded that the programme also led to an

Table 3

Mean scores on dimensions of psychosocial interventions

\begin{tabular}{|c|c|c|c|c|c|c|}
\hline \multicolumn{2}{|c|}{ Psychosocial interventions } & \multirow{2}{*}{$\begin{array}{l}\text { Condition } \\
\text { Experimental }\end{array}$} & \multirow{2}{*}{$\begin{array}{l}T_{1} \\
5.2(1.4)\end{array}$} & \multirow{2}{*}{$\begin{array}{l}\mathrm{T}_{2} \\
5.0(1.4)\end{array}$} & \multirow{2}{*}{$\begin{array}{l}T_{3} \\
5.3(1.3)\end{array}$} & \multirow{2}{*}{$\begin{array}{l}\text { Measurements } \times \\
\text { conditions } \\
F=1.04 \\
d f=2,101\end{array}$} \\
\hline Number & General (range: $0-8.9$ ) & & & & & \\
\hline & & Control & $4.9(1.4)$ & $5.2(1.3)$ & $5.2(1.4)$ & $P=0.18$ \\
\hline & Pain-focused (range: $0-8.9$ ) & Experimental & $5.5(2.0)$ & $5.5(1.8)$ & $5.3(1.7)$ & $\begin{array}{l}F=2.09 \\
d f=2,102\end{array}$ \\
\hline & & Control & $5.6(2.0)$ & $5.3(1.7)$ & $5.9(1.7)$ & $P=0.06$ \\
\hline \multirow[t]{4}{*}{ Duration } & General (range: $-26-26)^{\mathrm{b}}$ & Experimental & $0.0(0.0)^{\mathrm{c}}$ & $3.1(4.2)$ & $1.1(1.7)$ & $\begin{array}{l}F=8.29 \\
d f=2,102\end{array}$ \\
\hline & & Control & $0.0(0.0)^{\mathrm{c}}$ & $0.02(3.5)$ & $0.1(0.3)$ & $P<0.001$ \\
\hline & Pain-focused (range: $-8-8)^{b}$ & Experimental & $0.0(0.0)^{\mathrm{c}}$ & $1.7(2.2)$ & $1.1(1.7)$ & $\begin{array}{l}F=17.13 \\
d f=2,103\end{array}$ \\
\hline & & Control & $0.0(0.0)^{\mathrm{c}}$ & $-0.2(1.04)$ & $0.1(0.3)$ & $P<0.001$ \\
\hline \multirow[t]{4}{*}{ Quality } & General (range: $-26-26)^{\circ}$ & Experimental & $0.0(0.0)^{\mathrm{c}}$ & $2.6(4.3)$ & $2.3(4.6)$ & $\begin{array}{l}F-8.31 \\
d f=2,103\end{array}$ \\
\hline & & Control & $0.0(0.0)^{\mathrm{c}}$ & $0.3(0.8)$ & $0.5(1.3)$ & $P<0.001$ \\
\hline & Pain-focused (range: $-8-8)^{\mathrm{b}}$ & Experimental & $0.0(0.0)^{\mathrm{c}}$ & $1.6(2.1)$ & $1.0(1.8)$ & $\begin{array}{l}F=15.89 \\
d f=2,103\end{array}$ \\
\hline & & Control & $0.0(0.0)^{\mathrm{c}}$ & $0.03(0.2)$ & $0.03(0.4)$ & $P<0.001$ \\
\hline
\end{tabular}

"Square root transformed scores.

"The most favourable scores are in italic type.

'In actuality, there was no $T_{1}$ measurement for this dimension. As, however, a change in relation to $T_{1}$ is required at $T_{2}$ and $T_{3}$, a value of 0 was supplied for $T_{1}$. 
Table 4

Mean scores on dimensions of physical and relaxation interventions

\begin{tabular}{llllll}
\hline $\begin{array}{l}\text { Physical and relaxation } \\
\text { interventions }\end{array}$ & Condition & $\mathrm{T}_{1}$ & $\mathrm{~T}_{2}$ & $\mathrm{~T}_{3}$ & Measurements $\times$ conditions \\
\hline Number (range: $0-8.9)^{\mathrm{a} . \mathrm{h}}$ & Experimental & $5.2(1.4)$ & $5.4(1.3)$ & $5.2(1.4)$ & $\begin{array}{l}F=0.21 \\
d f=2,103\end{array}$ \\
& Control & $5.0(1.6)$ & $5.1(1.7)$ & $4.8(1.6)$ & $\begin{array}{l}P=0.40 \\
F=18.98\end{array}$ \\
Quality (range: $-12-12)^{\mathrm{b}}$ & Experimental & $0.0(0.0)^{\mathrm{c}}$ & $1.89(2.4)$ & $1.09(2.1)$ & $\begin{array}{l}\mathrm{d}=2,103 \\
P<0.001\end{array}$ \\
& Control & $0.0(0.0)^{\mathrm{c}}$ & $0.0(0.0)$ & $0.06(0.3)$ & $P<$ \\
\hline
\end{tabular}

${ }^{\mathrm{a}}$ Square root transformed scores.

"The most favourable scores are in italic type.

'In actuality, there was no $T_{1}$ measurement for this dimension. As, however, a change in relation to $T_{1}$ is required at $T_{2}$ and $T_{3}$, a value of 0 was supplied for $T_{1}$.

increase in the quality of pain-focused psychosocial interventions.

\subsection{Physical and relaxation interventions}

\subsubsection{Number}

Experimental nurses' as well as control nurses' numbers of physical and relaxation interventions vary somewhat over the three measurement points (Table 4). The number of physical and relaxation interventions is not affected by participation in the programme, which is indicated by the nonsignificant difference in trend between experimental and control nurses.

\subsubsection{Quality}

Experimental nurses do show an increase in the quality of their physical and relaxation interventions (Table 4 ). There is virtually no change in the quality of physical and relaxation interventions of control nurses. The difference in trend between the two groups is significant, and it can be concluded that the programme had a positive effect on the quality of physical and relaxation interventions.

\section{Conclusions}

The programme brought about in some, but not in every, respect the anticipated and desired changes. In the first place, there were no effects ascertained with regard to attitudes towards psychosocial interventions. This finding may be linked with a 'ceiling effect': before the programme $\left(T_{1}\right)$, the experimental nurses' average attitude score was already quite high (7.6 in a theoretical range of $0-10$ ).

In addition, no effects were ascertained on the number of psychosocial interventions. A possible explanation for this is that nurses who participated in the programme may evaluate their own interventions more critically than previously, in which case a greater number of interventions would not always be expressed in the scores [5,34]. However, if the scores do reflect the actual situation, the lack of increase in the number of psychosocial interventions may be connected to a lack of change in nurses' attitudes towards these interventions. In addition, the lack of increase in number may also be connected to the increase in quality of psychosocial interventions; carrying out high-quality interventions may be a top priority for nurses, but not a large number of interventions. Nurses indicated in the Adjusted Therapeutic Behaviour Scale changes concerning quality of psychosocial interventions with written comments such as: "I now project less my own ideas onto patients", "I pay more attention to patients' emotions and experiences, and go into them in greater depth", "I now involve patients more when providing information", "I provide more comprehensive information, for instance about the reasons for and methods of treatment".

Furthermore, the programme also resulted in an increase in the duration of psychosocial interventions. In view of empirical indications that 
psychosocial interventions (e.g. bedside talks) are often brief and superficial [7,9], an increase in duration can be considered as positive.

Although the programme had positively affected nurses' attitudes towards physical and relaxation interventions, the number of these interventions had not changed. This finding may be explained by qualitative interviews with programme participants [35], which indicated that nurses did not feel able to put physical and relaxation interventions frequently and regularly into practice. Among other factors, insufficient familiarity with massage, relaxation and distraction techniques, limited time and personnel, and a lack of formal implementation were stated as reasons.

However, the quality of physical and relaxation interventions did improve due to participation in the programme. In the Physical and Relaxation Interventions Questionnaire, nurses provided descriptions of these changes in quality, such as: "My information to the patient about these interventions is better and more thorough now", "I now demonstrate (relaxation) exercises myself", "I now ask patients what the effects of these interventions are".

All the positive effects are more observable 1 month after the programme than 6 months afterwards. Although the effects apparently diminish with time, they are still observable at the last measurement point. This is an indication that nurses have retained what they learned and integrated it in daily practice.

Continuing education for nurses is, however, not merely intended to bring about changes in nurses' behaviour. It becomes really worthwhile when it also produces positive results for paticnts. Another part of the study showed that patients' pain intensity was significantly lower among those attended by nurses who had completed the programme than among those cared for by control nurses (findings not yet published). It is, however, not completely clear whether the decrease in pain intensity can be attributed to the changes in interventions described in this article. Accordingly, an interesting question for future research is whether changes in nurses' psychosocial, physical and relaxation interventions are reflected in patients' experiences with these interventions, and, if so, whether this is connected to a decrease in pain intensity.

\section{Acknowledgements}

The authors would like to thank Suzanne Arts and Andrea de Schepper for their assistance in this study.

\section{References}

[1] Devine EC, Cook TD. A meta-analytic analysis of effects of psycho-educational interventions on length of post-surgical hospital stay. Nurs Res 1983; 32: 267-274.

[2] Devine EC, Cook TD. Cinical and cost-saving effects of psycho-educational interventions with surgical patients: a meta-analysis. Res Nurs Health 1986; 9: 89-105.

[3] Hathaway D. Effect of preoperative instruction on postoperative outcomes: a meta-analysis. Nurs Res 1986; 35 : 269-275.

[4] Mumford E, Schlesinger HJ, Glass G. The effects of psychological intervention on recovery from surgery and heart attacks: an analysis of the literature. $\mathrm{Am} \mathrm{J}$ Public Health 1982; 72: 141-151.

[5] Pool JJ. Sociaal-therapeutisch gedrag van verpleegkundigen (Social-Therapeutic Behaviour of Nurses). PhD Thesis. Amsterdam: Free University, 1983.

[6] Shade P. Patient-controlled analgesia: can client education improve outcomes? J Adv Nurs 1992; 17: 408-413.

[7] Armstrong-Esther CA, Browne KD, McAfee JG. Elderly patients: still clean and sitting quietly. I Adv Nurs 1994; 19: 264-271.

[8] Francke AL. Wat doen verplecgkundigen bij pijn (What do nurses in case of pain)? TVZ 1992; 102: 460-463.

[9] Maes H. De communicatie tussen patiënt en studentverpleegkundige: een exploratief onderzoek (The communication between patient and student nurse: an explorative study) [unpublished Master thesis]. Louvain: Catholic University, 1988.

[10] Hyman RB, Feldman HR, Harris RB, Levin RF, Malloy GB. The effects of relaxation training on clinical outcomes: a meta-analysis. Nurs Res 1989; 38: 216-221.

[11] Levin RF, Malloy GB, Hyman RB. Nursing management of post-operative pain: use of relaxation techniques with female cholecystectomy patients. J Adv Nurs 1987; 12: 463-472.

[12] Wells N. The effect of relaxation on post-operative muscle tension and pain. Nurs Res 1982; 31: 236-238.

[13] Cook JD. Music as an intervention in the oncology setting. Cancer Nurs 1986; 9: 23-28. 
[14] Locsin RGRAC. The effect of music on the pain of selected post-operative patients. J Adv Nurs 1981; 6: 19-25.

[15] Herr KA, Mobily PR. Interventions related to pain. Nurs Clin N Amer 1992; 27: 347-368.

[16] VWR/CBO. Syllabus bij de consensusbijeenkomst 'Verpleegkunde bij pijn' (Reader for the consensus meeting 'Nursing and pain). Itrecht: CBO, 1994.

[17] Fordham M, Dunn V. Alongside the person in pain. Holistic care and nursing practice. London: Baillère Tindall, 1994.

[18] McCaffery M, Beebe A. Pain. Clinical manual for nursing practice. St. I ouis, MO: C.V. Mosby, 1989.

[19] Barbour LA, McGuire DB, Kirchoff KT. Nonanalgesic methods of pain control used by cancer outpatients. ONF 1986; 13: 56-60.

[20] Dalton JA. Nurses' perceptions of their pain assessment skills, pain management practices, and attitudes toward pain. ONF 1989; 16: 225-231.

[21] Halfens R, Derks W, Huijer H. Verpleegkundige pijninterventies in Nederlandse ziekenhuizen. Een inventarisatie van opvattingen en praktijk (Nursing pain interventions in Dutch hospitals. A study concerning perceptions and practices). Verpleegkunde. NederlandsVlaams Tijdschrift voor Verpleegkundigen 1994; 8: $243-$ 250.

[22] Linde MJ van der. Het verpleegprobleem pijn bij terminale patiënten met kanker in de thuissituatie (Pain as a nursing problem in the care for terminal cancer patients at home). Proceedings of the 13th Congress of the 'Vereniging van Oncologie Verpleegkundigen' (Dutch community of oncology nurses), 1994; 75-78.

[23] Schuurmans J, Wulferink A, Boer H, Pijn bij kanker: Opvattingen van verpleegkundigen (Pain and cancer: nurses' perceptions). TVZ 1993; 3: 97-99.

[24] Itano J, Miller CA. Learning needs of Oncology Nursing Society members. ONF 1990; 17: 697-703.

[25] Sofaer B. The effect of focused education for nursing teams on post-operative pain of patients [unpublished PhD thesis]. Edinburgh: University of Edinburgh, 1984.

[26] Francke AL, Garssen B. Pijnbijscholingen: een literatuuroverzicht. Studies naar de effecten van pijnbijscholingen voor verpleegkundigen (Pain programmes: a literature review. Studies on the effects of continuing pain education for nurses). Verpleegkunde. NederlandsVlaams Wetenschappelijk Tijdschrift voor Verpleegkundigen 1995; 9: 199-208.

[27] Ferrell BR, Grant M, Ritchey KJ, Ropchan R, Rivera LM. The pain resource nurse training program: a unique approach to pain management. J Pain Symptom Manage 1993; 8: 549-556.

[28] Francke AL, Erkens MJM. Confluent education: an integrative approach for (nursing continuing) education. J Adv Nurs 1994; 19: 354-361.

[29] Ajzen I. Attitudes, personality, and behavior. Milton Keynes: Open University Press, 1988.

[30] Francke AL, Huijer Abu-Saad H, Grypdonck M. Pain assessment and management in surgical cancer patients: pilot and evaluation of a continuing education program. J Cont Educ Nurs 1995; 26: 214-218.

[31] Stevens J. Applied multivariate statistics for the social sciences. Hillsdale: Lawrence Erlbaum Associates, 1986.

[32] Boumans N. Het werk van verpleegkundigen in algemene ziekenhuizen. Een onderzoek naar werkaspecten en hun invloed op verpleegkundigen (Nursing practice in general hospitals. A study concerning aspects of nursing practice and their influence on nurses) $[\mathrm{PhD}$ Thesis]. Maastricht: University of Limburg, 1990.

[33] Bruggemans E, Maes S. Psychosociale effecten van een lange-termijn sportprogramma bij coronaire hartpatiënten (Psychosocial effects of a long term sports programme in coronary hart disease patients). De Psycholoog XXI: oktober 1986, 497-498.

[34] Sprangers M. Response shift and the retrospective pretest. On the usefulness of retrospective pretest-posttest designs in detecting training related response shift [PhD dissertation]. The Hague, The Netherlands: Institute for Education Research SVO, 1988.

[35] Lemmens ABT. Bijscholing en gedragsverandering. Een kwalitatieve studie naar factoren die van invloed zijn op gedragsverandering van bijgeschoolde verpleegkundigen (Continuing education and behavioural change. A qualitative study on factors which influence nurses' behavioural change after continuing education) [unpublished Masters thesis]. Maastricht: University of Limburg, 1994. 